\title{
The values of local wisdom contained in the Grebeg Sabrang traditional dance at Mangun Dharma art gallery
}

\author{
F.C. Chanada*, D. Sukriono \& R. Umar \\ State University of Malang, Malang, Indonesia \\ E.N. Hapsari \\ Universiti Malaya, Kuala Lumpur, Malaysia
}

\begin{abstract}
This study discussed the values of local wisdom contained in a traditional dance called Grebeg Sabrang dance, precisely at Padepokan Seni Mangun Dharma. This study aimed to introduce one of traditional dance that is still original from Padepokan Seni Mangun Dharma and the benefits provided by the Mangun Dharma Art Gallery to the Grebeg Sabrang dance in the preservation of local wisdom values. This study used a qualitative approach with descriptive study. Data collections techniques used interviews, observations, and documentation. Data analysis technique used interactif analysis. The results of this study showed Grebeg Sabrang Dance is a Malang traditional dance which is still original and has a lot of values of local wisdom.
\end{abstract}

Keywords: Grebeg Sabrang, traditional dance, local wisdom values

\section{INTRODUCTION}

Indonesia is a country that has a wide variety of cultures, ethnicities, races, religions and customs. Each region has its own characteristics that are unique and differentiate between regions, because the culture referred to here is an art that can be developed independently by the surrounding community. People are free to work and create according to their respective regions. Each region has traditional rituals, traditional ceremonies, and traditional dances that are different and unique to the area.

Dance is the rhythmic and beautiful movements of the human body. Every dance has its own beauty, and that beauty is relative. Dance is a combination of several elements, namely wiraga, wirama, and wirasa. The movements created in a dance must be in harmony with the accompanying music and there is an inspiration when dancing a dance (Sumaryono in Rahayuningtyas, 2015).

Besides the element of beauty, in a dance there are also values. In dance, there are symbols of life that have deep meaning and values about the nature of life (Pratiwi, 2016). In a traditional dance, the movements that are created usually contain symbols or improvements from the movements carried out, and are characteristic of an area. Based on cultural statistical data Hadi et al., 2019) Indonesian arts established by UNESCO in 2018 are Balinese dance, Saman dance, and Wayang performances.

Grebeg Sabrang dance is one of the traditional dances that must be maintained, because this is a traditional dance from the Malang area which is characteristic of the Malang area. Grebeg Sabrang dance is already attached to the Malang regional identity because the dance movement is a "Malangan" movement and is a standard dance that must always be maintained. There are local wisdom values contained in the Grebeg Sabrang dance. The importance of preserving the Grebeg

${ }^{*}$ Corresponding Author 
Sabrang dance is because this dance is a standard dance which until now has been made an icon of the Malang area.

It is very important to provide knowledge about traditional arts to the community, so that the values contained in a traditional art can be conveyed. The values contained in an art or culture will not emerge by itself if it does not try to express it in line with the many foreign cultures that have entered Indonesia (Gunawan \& Sulistyoningrum, 2013).

\section{METHODS}

This study used a qualitative approach with descriptive study. Descriptive research according to Creswell is a research method that seeks to describe and interpret objects as they are (Sangadji and Sopiah, 2010). This study was conducted by the author by being present in the field, precisely at the Mangun Dharma Art Gallery, Tumpang Sub District, Malang Regency. The data collections techniques used interviews, observations, and documentation. The data analysis technique used is Cresswell's interactive model which includes organizing and preparing data, reading all the data, making coding, using coding to describe, connecting between themes, and providing interpretation (Sugiyono, 2018).

\section{RESULTS AND DISCUSSION}

\subsection{The origins of the Grebeg Sabrang dance at the Mangun Dharma art gallery}

Grebeg Sabrang dance at Mangun Dharma Art Gallery is one of the traditional mask dances typical of Malang area created by an artist named Ki Soleh Adi Pramono in 1983When it was first created; the dance was called Grebeg Brang Wetanan Dance. In 1989, he officially founded an art studio called Padepokan Seni Mangun Dharma (Mangun Dharma Art Gallery). The padepokan houses various kinds of arts.

In 2001, the Grebeg Sabrang Dance was created by him to represent the Malang region as for the Indonesian Mask Dance event. Grebeg Sabrang dance is called the Grebeg Bolo Werto dance which means that werto is red. Then the name became the Grebeg Sabrang Dance which until now is known to the community around the Mangun Dharma Art Gallery. This is in accordance with the opinion of Sumaryono (2011) as quoted by Rahayuningtyas (2015) that dance is rhythmic and beautiful human body movements. The beauty of the movement can be seen from the non-physical side, namely the impression that comes from the dance arrangement. Grebeg Sabrang dance is a manifestation of a dance stylist or choreographer at the beginning of creating the dance and becoming a representative for the Malang area.

\subsection{Characteristic of the Grebeg Sabrang dance at the Mangun Dharma art gallery}

\subsubsection{Variety of movements}

The characteristics of the variety of movements are still original and have distinctive features. This can be seen from the addition of movement at each change of music. In addition, it has a large volume. The various movements include kanon movements, balan movements, there are top, bottom, middle designs, and so on. While the details of the dance movement include singget, gedheg mantuk, labas, trecet, gedrug or gedrugan, and ronggo lawe. The dashing character in the dance is emphasized by the hand attitude, namely the closed supit and the leg attitude which is called tanjek. The development movement includes maju gawang and solah motion.

\subsubsection{Gendhing}

The Grebeg Sabrang Dance at Mangun Dharma Art Gallery has a piece whose dominance is ayakayakan or so called krucilan accompaniment, because in the past it was used to accompany wayang 
krucilan. A gendhing is determined by cengkal kendang. Gendhing for the Grebeg Sabrang Dance at Mangun Dharma Art Gallery is 5 panthers, namely there are 10 pathets whose dominance is 4 pelog rhythms, because this dance is an all-night dance. Then the line is pathet 8 , in pathet 8 there is maujengkaran then go up to pathet 9 and return to pathet 8 again. After there is the first jejer, then there is the second jejer which is followed by Gunung Sari Dance.

\subsubsection{Costume}

The costumes from the Grebeg Sabrang Dance at the Mangun Dharma Art Gallery include: (1) Grebeg Sabrang masks; (2) Jamang; (3) Wigs; (4) Neck decoration; (5) Shoulder hanger; (6) Bracelet; (7) Pants; (8) Jarik; (9) Thigh Cover; (10) Black stagen; (11) Belt; (12) Sampur or shawl; (13) Keris; and (14) Gongseng. For the masks in the Grebeg Sabrang Dance, there are five characters consisting of: (1) Patih Lindumanon; (2) Patih Lindusekti; (3) Kala Memreng; (4) when wrapping his face; and (5) Gajah Sugwa.

\subsubsection{Staging}

There are two parts or episodes in the performance. In the first part the dancer enters the stage to dance the first part. In the second part, dancers enter the stage to describe the story of the soldier on the opposite side with the atmosphere of a journey that has approached the battlefield or the place to carry out their duties. The appearance or performance depends on the storyline that is performed by the dhalang.

\subsection{The meaning of Grebeg Sabrang dance at the Mangun Dharma art gallery}

\subsubsection{Social anthropology}

Grebeg Sabrang dance at Padepokan Seni Mangun Dharma means procession depicting soldiers coming out of the Alun-alun (the front yard of a kingdom). Patricia Dewar in the Journal of Dance Ethnology quoted by Rahayuningtyas (2015) states that dance as a movement communication system has social functions and uses. The meaning of the dance is a soldier from Prabu Klana Sewandana who is carrying out state duties. The large number of troops in the royal square makes it called grebegan. From a social perspective, this dance is seen from the meaning of the storyline and the elements contained. The narrative referred to is that the soldiers are carrying out state duties together. While the elements of the Grebeg Sabrang cannot stand alone. There are gamelan accompanists, costume stylists and spectators or audience.

\subsubsection{Art anthropology}

The performance is in the form of proseniumtis, which is a frame stage with the audience in one direction. The law of art in Grebeg Sabrang Dance is a choreographer who pays attention to group designs. The group dance design has a variety of elements which include the density of the number of dancers, floor patterns, and gendhing. The law of choreography is divided into two, namely meaningful motion and pure motion. Meaningful motion means having meaning or meaning in dance. For example, a movement called ronggo lawe in this dance depicts a king examining his army or soldiers. While pure motion has no meaning and is an original movement.

This is in line with the opinion of Rahayuningtyas (2015) that dance movements are movements that have undergone a change or stylization process from wantah and meaningful movements. The motion of wantah is very easy to understand because it is an original motion that has not yet received a touch of beauty. Meanwhile, the meaningful motion is a beautiful motion and has a lot of meaning.

\subsubsection{Philosophy anthropology}

Philosophical anthropology includes two physical and four inner keys. The two keys of birth or choreography include kawruh mengku and kawruh megeng. The inner keys include mapak, mengkal, megeng, and mapan. Each key has its own meaning. Mapak means pick up the rhythm, 
in which a dancer dances first to provoke gendhing. Mengkal is in accordance with the character who is detached. Megeng is an inspiration in a dance. Mapan is the harmony between the various movements and gendhing. If all keys can be mastered by the dancer, then a dancer can animate or unite with a dance.

\subsection{Local wisdom values in Grebeg Sabrang dance at the Mangun Dharma art gallery}

According to Mulyana, quoted by Frimayanti (2017) that value is a reference to belief in determining an option. Local wisdom according to Suyatno (2011), can be defined as a local cultural wealth that contains a life policy, namely a way of life which accommodates life wisdom. Almost every local culture in the archipelago is known for its local wisdom that teaches mutual cooperation, tolerance, work ethic, and so on. On the other hand, local wisdom can also be said to be a view of community life in the form of activities and used as a guide in carrying out various activities (Astuti, 2016).

\subsubsection{Religious value}

Local wisdom aims to increase welfare and create peace. The religious value is contained in the Grebeg Sabrang Dance. The religious value is shown in the appearance or performance and making of masks. In ancient times, people danced for good and approached God by means of art. Art is not just a thematic dance, but art is related to mystical science. The Grebeg Sabrang dance at the Mangun Dharma Art Gallery is associated with mystical science, both in the appearance and in the process of making masks.

\subsubsection{Mutual cooperation value}

The general meaning contained in the values of mutual cooperation depends on the form of mutual cooperation that is carried out, because each mutual cooperation has different values and meanings (Rolitia et al, 2016). The value of mutual cooperation shown in the storyline of the dance. The storyline in question is a depiction of the Grebeg Sabrang Dance. It depicts a group of warriors from Prabu Klana Sewandana who are fighting to carry out state duties.

\subsubsection{Moral value}

Moral values are educational values, namely educational values which include individual attitudes in personal life, social life, and life related to God (Nugraheni, 2018). The moral value is shown in every tradition that is still maintained today. The majority of the traditions are still maintained today, both from making masks, various movements, gendhing, and costumes. This is because Ki Soleh Adi Pramono respects the services of his ancestors, by maintaining traditions and customs. The making of masks in this dance is still very sacred and upholds tradition. This is evident from the highly respected politeness and ethics. Subadio (1986) as quoted by Brata, that local wisdom (local genius) as a whole includes, maybe even be considered the same as cultural identity which can be interpreted as the identity or cultural personality of a nation.

\subsubsection{Togetherness value}

The value of togetherness is shown in the appearance or performance of the dance. Performances always prioritize togetherness, so that the choreography and pieces can run in harmony. In addition, so that the meaning contained in the Grebeg Sabrang Dance can be conveyed.

\subsubsection{Educational value}

Values and education are aligned with a process of determining good and right in the framework of forming a person's personality towards a more mature direction and always adapting to their environment (Widagdo, 2014). The Grebeg Sabrang dance at Mangun Dharma Art Gallery contains educational values shown in the embodiment of the dance. Apart from the Mangun Dharma Art Gallery, this dance is also taught at schools and foreign dancers. Grebeg Sabrang dance is a 
traditional dance intended for the general public, so that everyone can learn the dance directly at the hermitage or gallery. Therefore, Mangun Dharma Art Gallery provides facilities for those who want to learn the dance. This is in line with the opinion of Santosa (2017) that local cultural wisdom is local knowledge that has been so integrated with belief systems, norms, culture, and expressed in traditions and myths that have been followed for a long time. The focus of the function and role of local wisdom is on three aspects, namely local wisdom, character, and character education. These three aspects can certainly be explored as cultural elements that are believed to be a strong binding force for the integrity of the Republic of Indonesia.

\subsubsection{Art value}

Cultural identity markers, for example, can come from a uniqueness that is believed to exist in religion, language and customs in the culture concerned (Maunati, 2004 in Brata). The art value is shown in the traditions that are in it, because the dance is still original and still maintains the tradition until now. Grebeg Sabrang Dance at Mangun Dharma Art Gallery is a unique traditional Malang art. Apart from being the identity and "icon" of the Malang area, the uniqueness lies in the characteristics of this Grebeg Sabrang Dance and does not exist in other arts.

\subsection{Benefits given by Mangun Dharma art gallery to the Grebeg Sabrang dance in preserving local wisdom values}

As a cultural heir, Mangun Dharma Art Gallery strives to maintain traditional arts which are characteristic of the Malang area. Both from the variety of movements, costumes, gendhing, meanings, and so on. It can be seen from the results of all the choreography and music creation processes of the Grebeg Sabrang Dance which have survived until now and there are still enthusiasts who want to learn this dance.

\section{CONCLUSIONS}

The origins of the Grebeg Sabrang Dance began in 1983 when Ki Soleh Adi Pramono would present a dance that represented the Malang area. The characteristics include a variety of movements, gendhing, costumes, and staging or performances. The meaning of the Grebeg Sabrang Dance includes: (a) Social anthropology; (b) Art anthropology; (c) Philosophical anthropology. The values of local wisdom in the traditional Grebeg Sabrang dance at Mangun Dharma Art Gallery can be concluded that there are six values of local wisdom, namely: (1) Religious value; (2) Mutual cooperation value; (3) Moral value; (4) Togetherness value; (5) Educational value; (6) Art value. Mangun Dharma Art Gallery provides defense efforts to all elements and traditions of the Grebeg Sabrang Dance.

\section{REFERENCES}

Astuti, F. 2016. Menumbuhkan nilai-nilai kearifan lokal melalui karya tari koreografer perempuan di Sumatera Barat: Suatu tinjauan gender. Humanus: Journal of Humaniora Sciences 15(1): 53-60.

Brata, I.B. 2016. Kearifan budaya lokal perekat identitas bangsa. Bakti Saraswati Journal 5(1): 120-136.

Frimayanti, A.I. 2017. Implementasi pendidikan nilai dalam pendidikan agama Islam. Islamic Education Journal of Lampung University 8(2): 227-244.

Gunawan, I. \& Sulistyoningrum, R. T. 2013. Menggali nilai-nilai keunggulan lokal kesenian reog Ponorogo guna mengembangkan materi keragaman suku bangsa dan budaya pada mata pelajaran ips kelas $\mathrm{v}$ sekolah dasar. Premiere Educandum: Primary Education and learning journal of PGRI Madiun University 3(1): 51-85.

Hadi, D.W. et al. 2019. Statistik kebudayaan 2019. Jakarta: Kementerian Kebudayaan dan Pendidikan Republik Indonesia (Ministry of Culture and Education of the Republic of Indonesia) 
Nugraheni, W. 2018. Penanaman nilai-nilai moral melalui kesenian reog kendang terhadap pelajar di Kabupaten Tulungagung. Imaji: Art and Education of Art Journal 16(2): 162-171.

Rahayuningtyas, W. 2015. Tari Topeng Malang. Malang: State University of Malang (UM Press)

Rolitia, M. et al. 2016. Nilai gotong royong untuk memperkuat solidaritas dalam kehidupan masyarakat kampung naga. Sosietas: Journal of Sociology Education 6(1). 23-32.

Sangadji, E.M. \& Sopiah. 2010. Metodologi penelitian. Yogyakarta: C.V Andi Offset

Santosa, E. 2017. Revitalisasi dan eksplorasi kearifan lokal (local wisdom) dalam konteks pembangunan karakter bangsa. Journal of Diponegoro University Semarang.

Sugiyono. 2018. Metode Penelitian Kuantitatf Kualitatif dan R\&D. Bandung: Alfabeta

Suyatno, S. 2011. Revitalisasi kearifan lokal sebagai identitas bangsa di tengah perubahan nilai sosiokultural. Journal of META SASTRA 4(1): 82-89.

Widagdo, S. \& Ermi D. K. 2014. Nilai pendidikan dalam upacara tradisi haul semangkin di Desa Mayong Lor Kecamatan Mayong Kabupaten Jepara. LINGUA: Journal of Language and Literature 10(1): 36-47. 